\title{
PERBANDINGAN ANALISIS NUMERIK MENGGUNAKAN METODE SECANT DAN METODE ITERASI SATU TITIK UNTUK MENENTUKAN KOEFISIEN GESEK UDARA PADA KUBUS DAN SILINDRIS
}

\author{
Linda Sekar Utami \\ Dosen Progran Studi Pendidikan Fisika Universitas Muhammadiyah Mataram \\ Email: lindasekarutami@gmail.com
}

\begin{abstract}
ABSTRAK
Koefisien gesek udara merupakan kemampuan udara untuk memberikan gesekan atau tahanan terhadap benda yang melaluinya, sehingga dapat memperlambat laju benda tersebut.Penelitian ini merupakan penelitian eksperimen laboratorium yang bertujuan untuk mengetahui perbedaan hasil analisis mengunakan metode secant dan metode iterasi satu titik dan menentukan nilai koefisien gesek udara (c) pada Kubus dan silinderis. Hasil dari penelitian dan pengamatan yang dilakukan dianalisi menggunakan metode secant dan metode iteasi satu titik. Nilai $v$ diperoleh dengan menurunkan persamaan $h(t)$ yang diperoleh dari grafik hubungan antara $h$ dan $t$ menggunakan Microsoft exel. Dengan menggunakan metode secant diperoleh kooefisien gesek (cg) pada kubus pada rentang antara $(0,21256-0,55411) \mathrm{kg} / \mathrm{s}$ sedangkan pada silindris berada pada rentang antara $(0,19252-0,46616) \mathrm{kg} / \mathrm{s}$ hal ini menujukan koefisien gesek udara yang dihasilkan dengan metode secant memiliki nilai yang konsatan baik pada kubus ataupun silinderis. Hal ini terjadi karna nilai $c g$ pada kubus dan silindris tersebut berada pada rentang orde $0<c g<1$. Dengan menggunakan metode iterasi satu titik diperoleh kooefisien gesek $(\mathrm{cg})$ pada kubus dengan rentang $(0,01674-0,12713) \mathrm{kg} / \mathrm{s}$ sedangkan pada silindris berada pada rentang antara $(0,01653-0,10046) \mathrm{kg} / \mathrm{s}$ hal ini menjukan koefisien gesek udara yang dihasilkan dengan metode iterasi satu titik memiliki nilai yang konsatan baik pada kubus ataupun silinderis. Dengan menggunakan metode secant nilai koefisien gesek udara yang di hasilakan berada dibawah nilai satu atau 0,1 sedangkan nilai koefisien yang dihasilkan dengan menggunakan pendekatan iterasi satu titik berada dibawah 0,01.Sehingga dapat disimpulkan metode iterasi satu lebih teliti dalam menentukan koefisien gesek udara dibandingkan dengan metode secant
\end{abstract}

Kata kunci: Koefisien gesek udara, metode secant, metode iterasi satu titik, kubus, silindris

\section{PENDAHULUAN}

Fisika merupakan ilmu pengetahuan yang sangat mendasar karna bersangkutan dengan struktur dan prilaku benda. Dalam aktivitas dan kehidupan kita sehari-hari sering kali kita menjumpai, mengamati ataupun memanfaatkan perinsip-prinsip dasar ilmu fisika. Bahkan ada peralatan yang dibuat dengan perinsip dasardasar fisika yang sudah akrab kita gunakan seperti mobil, hp dan lain sebagainya. Alat-alat tersebut ditemukan berdasarkan berbagai macam eksperimen dan riset menggunakan berbagai macam metode baik secara eksak maupun secara numerik

Persoalan yang melibatkan model matematika banyak muncul dalam berbagai disiplin ilmu pengetahuan. Seperti dalam bidang fisika, kimia, ekomomi atau dalam prsoalan rekayasa (engineering), seperti teknik sipil teknik mesin, elektero dan lain sebagainya. Seringkali model matematika muncul dalam dalam bentuk yang rumit.
Ketika metode analitik tidak dapat diterapkan karna masih dalam bentuk fersamaan matematika yang rumit, maka solusi yang dapat digunakan adalah dengan menggunakan metode numerik. Yang menjadi perbedaan metode numerik dan metode analitik adalah. Solusi dengan mengguanakan metode numerik selalu berbentuk angka, sendangkan dengan menggunakan metode analitik biasanya menghasilkan solusi dalam bentuk fungsi matematik (Munir Rinaldi, 2013:5)

Selama ini pelaksanaan percobaan tentang gerak benda jatuh bebas di SMA/MA hanya terbatas pada kondisi ideal, artinya tidak memperhitungkan faktor gaya gesek udara. Percobaan tersebut memenuhi syarat bila benda uji cukup berat, tetapi jika bendanya ringan, maka besarnya gesekan udara harus diperhitungkan.

Berdasarkan latar belakang diatas maka peneliti ingin melakukan penelitian dengan judul "Perbandingan Analisis Numerik 


\section{Menggunakan Metode Secant dan Metode Iterasi Satu Titik Untuk Menentukan Koefisien Gesek Udara Pada Kubus Dan Silinderis"}

\section{METODE PENELITIAN}

\section{A. Lokasi dan Waktu Penelitian}

Penelitian ini dilakukan di Laboratorium

Fisika FKIP Universitas Muhammadiyah Mataram pada tanggal 5 Januari sampai tanggal 6 Maret tahun 2014.

\section{B. Metode Penelitian}

Metode yang digunakan pada penelitian ini adalah metode eksperimental dengan percobaan di laboratorium.

\section{Ruang Lingkup Penelitian}

Adapun ruang lingkup penelitian ini adalah :

1. Fluida yang digunakan sebagai media adalah udara bebas.

2. Bentuk benda yang digunakan yaitu kubus dan slindris

3. Massa benda yang digunakan 0,078 $\mathrm{kg}$ dengan bentuk yang berbeda yaitu berbentuk silindris dan kubus yang disamakan masanya dengan plastisin

4. Tinggi fluida yang digunakan gaya ada sepuluh variasi ketinggian yaitu $0,6 \mathrm{~m}, 0,7 \mathrm{~m}, 0,8 \mathrm{~m}, 0,9 \mathrm{~m}, 1 \mathrm{~m}, 1,1 \mathrm{~m}$

5. Neraca yang digunakan adalah neraca digital

6. Untuk mengukur ketinggian digunakan mistar

7. Untuk mengukur waktu digunakan stopwatch dengan ketelitian 0,1

8. Untuk koefisien gesek fluida benda dijatuhkan dari ketinggian $0,6 \mathrm{~m}, 0,7$ $\mathrm{m}, 0,8 \mathrm{~m}, 1 \mathrm{~m}, 1,1 \mathrm{~m}$

9. Pada percobaan koefisien gesek diamati waktu yang dibutuhkan oleh benda untuk sampai ke dasar pada masing-masing titik ketinggian.

\section{Alat dan Bahan Penelitian}

Alat dan bahan yang digunakan dalam penelitian ini terdiri dari:

1. Stopwatch dengan ketelitian 0,1

2. Dua benda terbuat dari kayu berbentuk kubus dan silindris yang sedikit ditempelkan plastisin untuk menyamakan masanya

3. Tali pengikat

4. Tiang ukur

5. Mistar

\section{Neraca digital}

\section{E. Prosedur Penelitian} berikut:

Prosedur yang dilakukan adalah sebagai

1. Menentukan massa benda.

2. Menentukan titik ketinggian yang akan digunakan.

3. Menentukan batas ketinggian yaitu 60 $\mathrm{cm}, 70 \mathrm{~cm}, 80 \mathrm{~cm}, 90 \mathrm{~cm}, 100 \mathrm{~cm}, 110$ $\mathrm{cm}$,

4. Menjatuhkan benda secara bergiliran.

5. Mengamati stopwach kemudian mencatat waktu yang dibutuhkan untuk sampai ke dasar.

6. Mengulangi langkah 4 dan 5 sebanyak 3 kali.

\section{F. Desain penelitian}

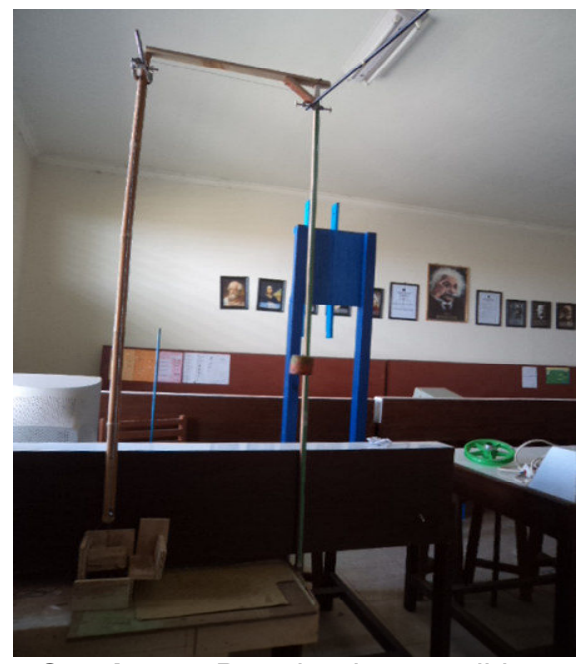

Gambar 1. Desain alat penelitian

\section{G. Metode Pengambilan Data}

Untuk menentukan massa benda digunakan neraca digital. Dengan menimbang masing-masing benda secara bergiliran dan menyesuaikan massa benda dengan kebutuhan penelitian. Adapun tabel pengamatannya sebagai berikut: 
Tabel 1. Pengamatan waktu jatuh benda

\begin{tabular}{|c|c|c|c|c|c|}
\hline \multirow[t]{2}{*}{ Benda } & \multirow[t]{2}{*}{ tinggi } & \multicolumn{3}{|c|}{ Percobaan ke- } & \multirow{2}{*}{$\begin{array}{c}\text { Rata } \\
\text {-rata } \\
\text { (s) }\end{array}$} \\
\hline & & 1 & 2 & 3 & \\
\hline \multirow[t]{6}{*}{ kubus } & 0.6 & 0,34 & 0,34 & 0,31 & 0.33 \\
\hline & 0.7 & 0,39 & 0,4 & 0,4 & 0.4 \\
\hline & 0.8 & 0,44 & $0,, 44$ & 0,41 & 0.43 \\
\hline & 0.9 & 0,47 & 0,48 & 0,48 & 0.48 \\
\hline & 1 & 0,50 , & 0,54 & 0,53 & 0.52 \\
\hline & 1.1 & 0,56 & 0,51 & 0,58 & 0.55 \\
\hline \multirow{6}{*}{$\begin{array}{l}\text { silindri } \\
\mathrm{s}\end{array}$} & 0.6 & 0,41 & 0,43 & 0,44 & 0.43 \\
\hline & 0.7 & 0,43 & 0,44 & 0,56 & 0.48 \\
\hline & 0.8 & 0,51 & 0,52 & 0,49 & 0.51 \\
\hline & 0.9 & 0,58 & 0,58 & 0,56 & 0.57 \\
\hline & 1 & 0,61 & 0,61 & 0,60 & 0.6 \\
\hline & 1.1 & 0,65 & 0,65 & 0,66 & 0.65 \\
\hline
\end{tabular}

Langkah-langkah tersebut diulangi untuk koofisien gesek udara pada ketinggian 0,6 m. $0,7 \mathrm{~m}, 0,8 \mathrm{~m}, 0,9 \mathrm{~m}, 1 \mathrm{~m}, 1,1 \mathrm{~m}$.

\section{H. Analisis Data}

\section{1. prosedur analisi data}

Dalam melakukan analisis data ada beberapa langkah yang dilakukkan. Data hasil pengamatan pada tabel 3.1 di maksukan kedalam program excel, dengan program excel diperoleh persamaan hubungan anatara ketinggian dan waktu. Dengan cara membelok kolom tabel ketinggian dan waktu selanjutnya pilih carths atau gerafik kemudian pilih starter selanjutnya pilih layout 9 sembilan, kemudian kelik kanan pada carths dan polih polynomial berordo 3 maka deperoleh persamaan hubungan antara $\mathrm{h}$ dan $\mathrm{t}$ dalam bentuk $\quad y=5,418 x^{3}-3,892 x^{2}+$
$2,428 x+0,024$ pada kubus dan $y=$ $13,29 x^{3}-22,14 x^{2}+14,41 x-2,562$ pada silindris.

Dengan menurunkan persamaan hubungan $\mathrm{h}$ dan t pada kubus dan slindris maka diperoleh persamaan laju kecepatan pada kubus dan silindris. Selanjutnya dengan mensibtitusikan waktu rata jatuh benda pada semua ketinggian dengan mengganti variabel $x$ dengan $t$ sehingga diperoleh kecepatan masing-masing benda untuk semua ketinggian. Selanjutnya dengan mensibtitusikan nilai keceapatan, masa benda dan gaya gravitasi bumi, kedalam persamaan 2.14 maka diperolehlah persamaan hambatan udara pada kubus dan silindris. Selanjuntnya hasil perhitungan dengan menggunakan persamaan 2.14, Dianalisa dengan mengguanakan metode secant pada persamaan 2.2 dan metode iterasi satu titik pada persamaan 2.4 baik pada kubus atapun pada silindris sehingga diproleh nilai koefisien gesek udara pada kubus ataupun silindeis

\section{Pengukuran Berulang}

Dalam melakukan pengukuran selalu terjadi ketidakpastian karena itu eksperimen ini sangat perlu dilakukan dengan pengulangan beberapa kali guna mendapatkan hasil yang lebih medekati nilai yang benar dan yang diharapkan.

\section{Penentuan Nilai Rata-Rata}

Dari sejumlah pengukuran yang dilakukan dicari nilai rata-rata dari nilai yang diperoleh. Untuk menentukan nilai rata-rata digunakan persamaan.

$$
x_{r}=\frac{\sum x_{n}}{n}
$$

\section{Menentukan nilai Standar Deviasi dan Ketidakpastian pengukuran Berulang}

Guna untuk memperoleh hasil pengukuran yang lebih meyakinkan perlu diketahui pula nilai ketidakpastian dari pengukuran tersebut. Untuk menentukan nilai ketidakpastian digunakan persamaan

$$
x=x_{r} \pm \Delta x
$$

sehingga hasil pengukuran dapat ditulis seperti pada persamaan

$$
\Delta x=\mathrm{d}_{\text {terbesar }}
$$




\section{Menentukan Koefisien Gesek Fluida}

Untuk menentukan koefisien gesek pada fluida, kita tentukan terlebih dahulu titik terminal masing-masing benda kemudian dirata-ratakan. Setelah itu tentukan sepuluh titik dasar sebagai variasi ketinggian. Kemudian mengamati waktu yang dibutuhkan untuk masing-masing benda untuk mencapai dasar masingmasing ketinggian. Selanjutnya untuk menghitung kecepatan benda menggunakan polynomial yaitu dengan membuat grafik $h$ terhadap $t$, sehingga diperoleh persamaan fungsi ketinggian terhadap waktu yang kemudian diturunkan menjadi fungsi kecepatan.

\section{HASIL DAN PEMBAHASAN}

Pada pengamatan ini menggunakan dua jenis bentuk benda yang berbeda dengan masa yang sama yaitu, benda yang berntuk kubus dan benda yang berbentuk silindris dengan bahan dasarnya terbuat dari kayu dengan beberapa permukaanya dilapisi plastisin untuk menyamakan masanya

\section{Kubus}

Dari hasil penelitian dan pengamatan yang dilakukan pada kayu yang berbentuk kubus yang dilapisi pelastisin di beberapa permukaannya untuk menyamakan masa 0,078 $\mathrm{Kg}$ diperlihatkan pada table 2:

Tabel 2 Data hasil pengamatan waktu pada kubus

\begin{tabular}{cccc}
\hline $\mathrm{N} 0$ & $\mathrm{t}(\mathrm{s})$ & $\mathrm{H}$ & $\Delta t$ \\
\hline 1 & 0,33 & 0,6 & 0,01 \\
2 & 0,4 & 0,7 & -0.01 \\
3 & 0,43 & 0,8 & $-0,02$ \\
4 & 0,48 & 0,9 & 0 \\
5 & 0,53 & 1 & 0,01 \\
6 & 0,55 & 1,1 & 0,03 \\
\hline
\end{tabular}

Penelitian ini menggunakan pengukuran berulang sehingga terdapat nilai ketidak pastian. Nilai ketidakpastian pada table 4.1 di atas dihitung menggunakan persamaan 2.20 , berada pada rentang $((-0,01)-(0,03)) \mathrm{s}$.

Hasil pengamatan waktu pada masingmasing ketinggian yang telah di tentukan pada penlitian ini yang terdapat pada table 4.1 diolah menggunakan program excel sehingga di peroleh persamaan fungsi ketinggian terhadap waktu

\section{Fungsi $\mathrm{h}$ terhadap $\mathrm{t}$}

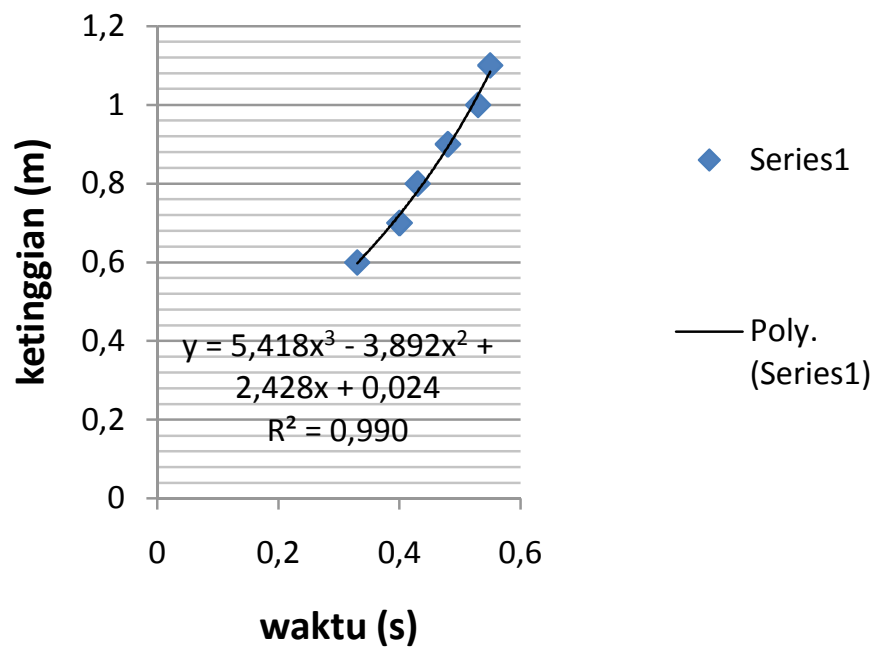

Gambar 2. Grafik Fungsi h Terhadap t

Table 4. Nilai cg Dengan Metode Iterasi Satu Titik Pada Kubus

\begin{tabular}{ccccc}
\hline N0 & $\mathrm{t}(\mathrm{s})$ & $\mathrm{h}$ & $\mathrm{v}$ & $c g$ \\
\hline 1 & 0,33 & 0,6 & 1,6293406 & 0,554117156 \\
2 & 0,4 & 0,7 & 1,91504 & 0,4048447032 \\
3 & 0,43 & 0,8 & 2,0862446 & 0,369515734 \\
4 & 0,48 & 0,9 & 2,4366016 & 0,300513018 \\
5 & 0,53 & 1 & 2,8682286 & 0,235915085 \\
6 & 0,55 & 1,1 & 3,063635 & 0,212558195 \\
\hline
\end{tabular}

Dalam analisis matematika menyebutkan bahwa besaran nilai yang belum diketahui dengan variable $\mathrm{x}$ dan sisanya yang belum diketahi dengan variabel y. (Filsafat matematika 2007:24 ). Dari grafik 4.1 yaitu grafik fungsi $h$ terhadap $t$ pada kubus diperoleh persamaan $\mathrm{y}=5,418 \mathrm{x}^{3}-3,892 \mathrm{x}^{2}+2,428 \mathrm{x}+$

0,024 Konsep kalkulus digunakan untuk menghitung kontinuitas laju perubahan kecapatan setiap waktu itu berlangsung (filsafat matematika). Dari persamaan fungsi h terhadap $t$ dapat diperoleh persamaan laju kecepatan benda (kubus) dengan menurunkan persamaan $y=5,418 x^{3}-3,892 x^{2}+2,428 x+$ 0,024 sehinggga $y^{\prime}=v=16,254 x^{2}-$ $7,784 x+2,428$ 
Dengan mengganti variabel $x$ dengan nilai t, maka dapat diperoleh laju kecepatan pada masing-masing ketinggian yang telah di tentukan dalam penelitian ini

Tabel 3 Data Hasil Perhitungan Kecepatan

\begin{tabular}{cccc}
\hline N0 & $\mathbf{t}(\mathbf{s})$ & $\mathbf{h}$ & $\mathbf{v}$ \\
\hline & 0,33 & 0,6 & 1,6293406 \\
2 & 0,4 & 0,7 & 1,91504 \\
3 & 0,43 & 0,8 & 2,0862446 \\
4 & 0,48 & 0,9 & 2,4366016 \\
5 & 0,53 & 1 & 2,8682286 \\
6 & 0,55 & 1,1 & 3,063635 \\
\hline
\end{tabular}

Dengan mengetahui hasil dari nilai laju kecepaatan, kemudian dengan fungsi persamaaan 2.14 digunakan untuk menentukan koefisien gesek udara dengan pendekatan metode secant dan metode itersi satu titik. Dimana nilai, gaya gravitasi $10 \mathrm{~m} / \mathrm{s}$ dan masa $(0,078 \mathrm{~kg})$

$$
\begin{gathered}
f(c)=3\left(\frac{v}{g m}\right)^{4} c_{g}^{3}+4\left(\frac{v}{g m}\right)^{3} c_{g}^{2}+6\left(\frac{v}{g m}\right)^{2} c_{g} \\
+12\left(\frac{v}{g m}-\frac{t}{m}\right)
\end{gathered}
$$

Dari hasil perhitungan dengan menggunakan persamaan 2.14 diatas, kemudian dianalisis menggunakan pendekatan metode secan dan metode iterasi satu titik sehingga di peroleh dinilai pendekatan $c g$

\section{Metode Secant Pada Kubus}

Table 4.3 Hasil Perhitungan Nilai cg Pada Kubus Dengan Metode Secant

Hasil perhitungan nilai $c g$ dengan pendekatan metode secant pada kubus yang berada pada table 4.3 nilai koefesien gesek udara pada rantang $(0,21255-0,55411) \mathrm{kg} / \mathrm{s}$.

\section{Dengan pendekatan iterasi satu titik berada pada kubus}

Tabel 4. Nilai $\mathrm{cg}$ Dengan Metode Iterasi Satu Titik Pada Kubus

\begin{tabular}{ccccc}
\hline $\mathrm{N} 0$ & $\mathrm{t}(\mathrm{s})$ & $\mathrm{h}$ & $\mathrm{v}$ & $\mathrm{Cg}$ \\
\hline 1 & 0,33 & 0,6 & 1,6293406 & 0,127128542 \\
2 & 0,4 & 0,7 & 1,91504 & 0,0870826 \\
3 & 0,43 & 0,8 & 2,0862446 & 0,066957311 \\
4 & 0,48 & 0,9 & 2,4366016 & 0,03950412 \\
\hline
\end{tabular}

\begin{tabular}{ccccc}
\hline 5 & 0,53 & 1 & 2,8682286 & 0,021612731 \\
6 & 0,55 & 1,1 & 3,063635 & 0,016743852 \\
\hline
\end{tabular}

Dengan pendekatan iterasi satu titik pada kubus nilai koefisien gesek udara (cg) Berada pada rentang $(0,01674-0,12713) \mathrm{kg} / \mathrm{s}$.

\section{Sillindris}

Dari hasil penelitian dan pengamatan yang dilakukan pada kayu yang berbentuk silindris dilapisi pelastisin untuk menyamakan masa $0,078 \mathrm{~kg}$

Tabel 5. Hasil Pengamaatan Waktu Pada Silindris

\begin{tabular}{cccc}
\hline $\mathrm{N} 0$ & $\mathrm{t}(\mathrm{s})$ & $\mathrm{H}$ & $\Delta t$ \\
\hline 1 & 0,43 & 0,6 & 0.01 \\
2 & 0,48 & 0,7 & 0 \\
3 & 0,51 & 0,8 & 0 \\
4 & 0,57 & 0,9 & $-0,01$ \\
5 & 0,6 & 1 & 0 \\
6 & 0,65 & 1,1 & 0 \\
\hline
\end{tabular}

Penelitian ini menggunakan pengukuran berulang sehingga terdapat nilai ketidak pastian. Nilai ketidakpastian pada table 4.1 di atas dihitung menggunakan persamaan 2.20, berada pada rentang $((-0,01)$ Sampai 0,01$))$ s.

Hasil pengamatan waktu pada masingmasing ketinggian yang telah di tentukan pada penlitian ini yang terdapat pada table 4.1 diolah menggunakan program excel sehingga di peroleh persamaan fungsi ketinggian terhadap waktu

\section{Fungsi $h$ terhadap $t$}

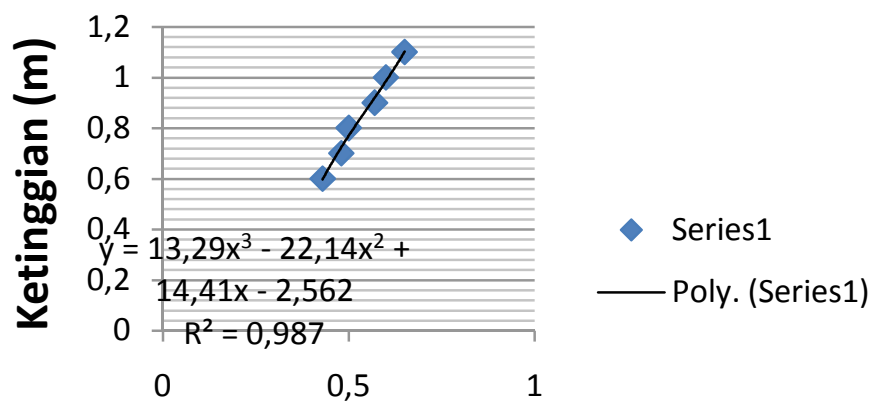

\section{Waktu (s)}

Gambar 3. Grafik Fungsi h terhadap t pada silindris 
Grafik 4.4 diatas adalah grafik fungsi $h$ terhadap t. Dalam analisis matematika kita menyebutkan besaran nilai yang belum kita ketahui dengan pariable $\mathrm{x}$ dan sisanya yang belum kita ketahui dengan y (Filsafat Matematika,2007:24)

Dari grafik fungsi $\mathrm{h}$ terhadap $\mathrm{t}$ diperoleh persamaan $\quad y=13,29 x^{3}-22,14 x^{2}+$ $14,41 \mathrm{x}-25,62$

Konsep kalkulus digunakan untuk menghitung kontinuitas laju perubahan kecapatan setiap waktu itu berlangsung. Dimana persamaan fungsi $h$ terhadap $t$ dapat diperoleh persamaan laju kecepatan Silindris dengan menurunkan persamaan $y=13,29 \mathrm{x}^{3}-$ $22,14 \mathrm{x}^{2}+14,41 \mathrm{x}-25,62$ Sehinggga $y^{\prime}=v=36,88 x^{2}-44,28 x+14,4114,41$

Dengan mengganti variable $x$ dengan nilai t maka dapat diperoleh leju kecepatan untuk masing-masing ketinggian yang telah di tentukan dalam penelitian ini

Tabel 6. Hasil perhitungan kecepatan

\begin{tabular}{cccc}
\hline No & Waktu t $(\mathrm{s})$ & $\mathrm{h}(\mathrm{cm})$ & $\mathrm{v}(\mathrm{m} / \mathrm{s})$ \\
\hline 1 & 0,43 & 0,6 & 2,741563 \\
2 & 0,48 & 0,7 & 2,341648 \\
3 & 0,51 & 0,8 & 2,197387 \\
4 & 0,57 & 0,9 & 2,124163 \\
5 & 0,6 & 1 & 2,401552 \\
6 & 0,65 & 1,1 & 2,473075 \\
\hline
\end{tabular}

Dengan mengetahui hasil dari nilai laju kecepaatan, kemudian dengan fungsi persamaaan 2.14 digunakan untuk menentukan koefisien gesek udara dengan pendekatan metode secant dan metode itersi satu titik. Dimana , gaya gravitasi $10 \mathrm{~m} / \mathrm{s}$ dan masa $(0,078 \mathrm{Kg})$

$$
\begin{gathered}
f(c)=3\left(\frac{v}{g m}\right)^{4} c_{g}^{3}+4\left(\frac{v}{g m}\right)^{3} c_{g}^{2} \\
+6\left(\frac{v}{g m}\right)^{2} c_{g} \\
+12\left(\frac{v}{g m}-\frac{t}{m}\right)
\end{gathered}
$$

Dengan menggunakan pendekatan metode secan dan metode iterasi saru titik pada hasil perhitungan pegamatan di atas maka di proleh nilai $c g$ pada silindris

\section{Dengan menggunakan pendekatan metode secant}

Tabel 7. Hasil perhitungan nilai $c g$ dengam metode secant pada silindris

\begin{tabular}{ccccc}
\hline No & $\begin{array}{c}\text { Waktu } \\
\mathrm{t}(\mathrm{s})\end{array}$ & $\begin{array}{c}\text { Ketinggian } \\
(\mathrm{m})\end{array}$ & $\mathrm{v}$ & $c g$ \\
\hline 1 & 0,43 & 0,6 & 2,741563 & 0,19252 \\
& & & & 4829 \\
2 & 0,48 & 0,7 & 2,341648 & 0,32721 \\
& & & & 916 \\
3 & 0,51 & 0,8 & 2,197387 & 0,39619 \\
& & & & 2816 \\
4 & 0,57 & 0,9 & 2,124163 & 0,46615 \\
& & & & 8849 \\
5 & 0,6 & 1 & 2,401552 & 0,40995 \\
& & & & 9581 \\
6 & 0,65 & 1,1 & 2,473075 & 0,39351 \\
& & & & 3997 \\
\hline
\end{tabular}

Hasil perhitungan nilai koefisien gesek udara $(c g)$ dengan pendekatan metode secant pada kubus berada pada rantang $(0,19252-$ $0,46616) \mathrm{kg} / \mathrm{s}$

\section{Dengan pendekatan iterasi satu titik}

Tabel 8. Nilai $c g$ Dengan Metode Iterasi Satu Titik

\begin{tabular}{ccccc}
\hline $\begin{array}{c}\mathrm{N} \\
\mathrm{o}\end{array}$ & $\begin{array}{c}\text { Wakt } \\
\text { u t } \\
\text { (s) }\end{array}$ & $\begin{array}{c}\text { Ketinggia } \\
\mathrm{n}(\mathrm{m})\end{array}$ & $\mathrm{v}$ & $c g$ \\
\hline 1 & 0,43 & 0,6 & $\begin{array}{c}225,3251 \\
3\end{array}$ & $\begin{array}{c}0,0165284 \\
79\end{array}$ \\
& & & 231,5484 & $\begin{array}{c}0,0478555 \\
76\end{array}$ \\
2 & 0,48 & 0,7 & 8 & $\begin{array}{c}23 \\
\end{array}$ \\
3 & 0,51 & 0,8 & 232,853 & 0,0719173 \\
& & & 64 \\
4 & 0,57 & 0,9 & $\begin{array}{c}232,0871 \\
3\end{array}$ & $\begin{array}{c}0,1004572 \\
03\end{array}$ \\
& & & 223,0275 & 0,0703925 \\
5 & 0,6 & 1 & 2 & 19 \\
& & & 221,0562 & 0,0633517 \\
6 & 0,65 & 1,1 & 5 & 79 \\
\hline
\end{tabular}

Hasil perhitungan nilai koefisien gesek udara (cg) pada silinderis dengan pendekatan metode iterasi satu titik berada pada rantang $(0,01653-0,10046) \mathrm{kg} / \mathrm{s}$

\section{Pembahasan}

Sistem kerja alat pada penelitian ini menggunakan system mekanik getar, dimana stopwatch yang bekerja pada alat ini hidup ketika penjepit dilepaskan dari dua benang yang mengikat dua buah benda,yaitu benda yang berada di atas tombol on pada stopwatch. 
Benda yang satunya adalah benda yang jatuh dari ketinggian tertentu, getaran yang dihasilakan oleh jatuhnya benda akan mengakibatkan benda yang diatas tombol off pada stopwatch bergetar sehingga akan menyebabkan stopwatch akan mati. Namun alat yang digunankan ini masih sangat sederhana sehigga boleh jadi terjadi kekeliruan pada penelitian atau ketidak pastian sehingga terjadi perbedaan nilai $c g$ pada masing-masing ketinggian baik pada kubus ataupun silindris.

Bedasarkan hasil analisis data yang diperoleh pada percobaan yang sudah dilakukan dengan menggunakan metode secant dan metode iterasi satu titik terdapat perbedaan koefisien gesek yang dihasilkan oleh metode iterasi satu titik dan metode secant baik dalam benda yang berbentuk kubus ataupun silinderis.

Dengan menggunakan metode secant diperoleh kooefisien gesek ( $c g$ ) pada kubus $(0,21256$ - 0,55411$) \mathrm{Kg} / \mathrm{s}$ sedangkan pada silindris berada pada rentang antara $(0,19252$ $0,46616) \mathrm{Kg} / \mathrm{s}$ hal ini menjukan koefisien gesek udara yang dihasilkan dengan metode secant memiliki nilai yang konsatan baik pada kubus ataupun silinderis. Hal ini terjadi karna nilai $c g$ pada kubus dan silindris tersebut berada pada rentang orde $0<c g<1$

Dengan menggunakan metode iterasi satu titik diperoleh kooefisien gesek $(\mathrm{cg})$ pada kubus $(0,01674$ - 0,12713$) \mathrm{kg} / \mathrm{s}$ sedangkan pada silindris berada pada rentang antara rantang $(0,01653-0,10046) \mathrm{kg} / \mathrm{s}$ hal ini menjukan koefisien gesek udara yang dihasilkan dengan metode secant memiliki nilai yang konsatan baik pada kubus ataupun silinderis. Hal ini terjadi karna nilai $c g$ pada kubus dan silindris tersebu berada pada rentang orde $0<c g<1$.

Nilai $c g$ yang diperoleh sangat kecil, nilai $c g$ yang dihasilakan dengan menggunakan metode secant kurang dari 1 atau dibawah 0,1 sedangkan nilai $c g$ yang dihasilkan dengan menggunakan metode itrasi satu titik dibawah 0,01 . Ini menunjukan bahwa metode iterasi satu titik lebih teliti dibandingkan dengan metode secant. Nilai $c g$ yang dihasilkan kurang dari 1 ,hal ini bisaterjadi karna udara memiliki susunan yang tidak teratur dan berjauhan sehingga kemungkinan untuk bergesek dengan benda yang melewatinya sangatlah kecil.

Dalam peroses pengambilan data ini tentunya ada kendala-kendala yang ditemukan, diantaranya sering terjadi kekeliruan seperti getaran yang berlebihan yang menyebabkan stopwatchnya hidup dan mati dalam waktu yang besamaan sehingga pengamatan harus diulang sampai mendapatkan data yang benar. Tetapi, hasil penelitian yang didapatkan cukup teliti karna kesalahan-kesalah pada saat pengukuran dapat diminimalisir dengan melakukan pengukuran lebih sering lagi pada setiap ketinggian sampai data yang diperoleh cukup meyakinkan.

\section{SIMPULAN DAN SARAN}

\section{A. Simpulan}

Dari pembahasan diperoleh beberapa

kesimpulan, diantaranya

1. Nilai koefisien gesek udara dengan menggunakan pendekatan metode secant pada kubus dan silinderis. Dengan menggunakan metode secant diperoleh kooefisien gesek $(\mathrm{cg})$ pada kubus $(0,21253$ sampai 0,55411) $\mathrm{kg} / \mathrm{s}$ sedangkan pada silindris berada pada rentang antara $(0,19252$ sampai 0,46616$) \mathrm{kg} / \mathrm{s}$. Dengan menggunakan metode iterasi satu titik pada kubus dan silindris diperoleh kooefisien gesek (cg) pada kubus (0,01674 sampai $0,12713) \mathrm{kg} / \mathrm{s}$ sedangkan pada silindris berada pada rentang $(0,01653$ sampai $0,10046) \mathrm{Kg} / \mathrm{s}$

2. Koefisien gesek udara dengan menggunakan metode secant dan menggunakan metode iterasi satu titik terdapat perbedaan nilai koefisien dengan menggunakan metode secant berada dibawah nilai satu atau 0,1 sedangkan nilai koefisien yang dihasilkan dengan menggunakan pendekatan iterasi satu titik berada dibawah 0,01 . Dari data yang diperoleh dapat disimpulakan bahwa metode iterasi satu titik lebih teliti dibandingkan dengan menggunakan metode secant dalam menentukan koefisien gesek udara, hal ini terjadi karna masing - masing metode numeric memiliki kelemahan dan kekurangan dalam menganalisis setiap permasalahan.

\section{B. Saran}

Berdasarkan penelitian yang sudah dilakukan, ada beberapa saran yang ingin penulis sampaikan, antara lain.

1. Perlu adanya penelitian yang lebih lanjut dengan membuat alat yang lebih baik dari penelitian ini

2. Peneliti kedepannya harus memiliki tingkat ketelitian yang lebih tinggi lagi

3. Untuk peneliti - peneliti selanjutnya, penulis sarankan untuk menggunakan sensor yang memiliki kepekaan untuk 
menangkap gerak maupun bunyi sehingga data yang didapatkan lebih akurat dan meyakinkan

\section{DAFTAR PUSTAKA}

Bresnick Stephen, 2002, Intisari Fisika, (diterjemahkan oleh : dr. J. F. Gabriel). Jakarta: Hipokrates.

Departemen Pendidikan Nasional. 2012.Kimia Fisika. Surakarta

Fardiaz Srikandi. 1992. Polusi Air dan Udara. Yogyakarta: Konisius

Gabriel, J.F. 2001. Fisika Lingkungan. Jakarta: Hipokrates

Munif Abd. 1995. Cara Praktis Penguasaan dan Penggunaan Metode Numerik. Surabaya: PT Candimas Metropole

Mudjiarto R dan Krips F.J. 1995. Fisika Matematik I. Bandung: ITB.

Raharjo Trustho dan Radiyono, Y. 2008. Fisika Mekanika. Surakarta: LPP UNS dan UNS Press.

Setiawan Agus. 2006. Pengantar Metode Numerik. Yogyakarta: ANDI.

Alisah Evawati. 2007. Filsafat Matematika. Jakarta:Prestasi Pustaka.

Haliday dkk. Dasar-dasar fisika jilid 1. Tanggerang:Bina Rupa Aksara Publisher.

Munir Rinaldi. 2013. Metode Numerik. Bandung: Informatika Bandung.

Sugandji. 2008. Metode Numerik. Yogyakarta: Graha IImu.

Sabariah. 2013. Menghitung Besar Koefisien Gesek Udara Pada Bola Dan Limas Segitiga Menggunakan Pendekatan Newton Rephson. Mataram: Universitas Muhammadiyah Mataram. 